\title{
Histone H1t
}

National Cancer Institute

\section{Source}

National Cancer Institute. Histone H1t. NCI Thesaurus. Code C162866.

Histone H1t (207 aa, $22 \mathrm{kDa}$ ) is encoded by the human H1-6 gene. This protein plays a role in chromatin condensation. 